\title{
Hepatic metabolic response of Holstein cows in early and mid lactation is altered by nutrient supply and lipopolysaccharide in vitro
}

\author{
M. Garcia, B. J. Bequette, ${ }^{1}$ and K. M. Moyes ${ }^{2}$ \\ Department of Animal and Avian Sciences, University of Maryland, College Park 20742
}

\begin{abstract}
The metabolic response of the liver during periods of inflammation is poorly understood. The objective of this study was to characterize the effects of nutrient supply and lipopolysaccharide (LPS) challenge on hepatic intermediate metabolism of early- and midlactation cows by employing gas chromatography-mass spectrometry with stable isotope tracer. Twelve multiparous Holstein-Friesian cows in early $(\mathrm{n}=6 ; 12 \pm 4.2 \mathrm{~d}$ in milk) and mid ( $\mathrm{n}=6 ; 115 \pm 13.5 \mathrm{~d}$ in milk) lactation were used for this study. Liver biopsies were performed on all cows. Liver slices (40-60 mg) were incubated in a $37^{\circ} \mathrm{C}$ water bath for $2 \mathrm{~h}$ with either control (phosphate buffered saline), pyruvate (PYR; $1 \mathrm{~m} M$ unlabeled pyruvate and $1 \mathrm{mM}\left[{ }^{13} \mathrm{C}_{3}\right]$ pyruvate), pyruvate + propionate (PYR+PRO; $1 \mathrm{~m} M$ unlabeled pyruvate, $1 \mathrm{mM}\left[{ }^{13} \mathrm{C}_{3}\right]$ pyruvate, and $2 \mathrm{~m} M$ sodium propionate), or pyruvate + AA (PYR+AA; $1 \mathrm{~m} M$ unlabeled pyruvate, $1 \mathrm{~m} M\left[{ }^{13} \mathrm{C}_{3}\right]$ pyruvate, and $2 \mathrm{mM}$ AA solution), and LPS (0.0 or 0.2 $\mu \mathrm{g} / \mathrm{mL}$ ) was added to flasks per treatment. Enrichment of isotopomers in metabolic equilibrium with Krebs cycle intermediates was assessed. Pyruvate fluxes and the enzymatic activity of pyruvate carboxylase (PC) versus pyruvate dehydrogenase $(\mathrm{PDH})$ and phosphoenol pyruvate carboxykinase (PEPCK) were calculated. Media were analyzed for concentrations of tumor necrosis factor- $\alpha(\mathrm{TNF}-\alpha)$, glucose, and haptoglobin. Data were analyzed as randomized block (stage of lactation) design in a factorial arrangement of nutrient treatments by LPS dose. Challenge with LPS increased the mRNA abundance of TNF- $\alpha$, haptoglobin, and serum amyloid A 2, and the concentration of TNF- $\alpha$ in media. Challenge with LPS increased mRNA abundance of PC but reduced the enrichment of ${ }^{13} \mathrm{C}_{1}[\mathrm{M} 1]$ and ${ }^{13} \mathrm{C}_{2}$ [M2] alanine and tended to reduce the enzymatic activity of PEPCK. Incubation with PYR+PRO and PYR+AA increased the flux of pyruvate to acetyl CoA. However,
\end{abstract}

\footnotetext{
Received October 28, 2014.

Accepted May 10, 2015.

${ }^{1}$ Deceased.

${ }^{2}$ Corresponding author: kmoyes@umd.edu
}

only PYR $+\mathrm{PRO}$ increased the enzymatic activity of PEPCK and PDH versus PC and decreased the mRNA abundance of PC. Cows in early lactation tended to receive a greater contribution of pyruvate to the oxaloacetate flux via the lower PDH versus PC activity and a higher mRNA abundance of PC than cows in mid lactation. Our results suggest that regardless of stage of lactation and nutrient supplement, hepatic gluconeogenesis was impaired during inflammation. Further research examining how various nutrients support liver function and improve the immunometabolic response of liver during inflammation is warranted.

Key words: Holstein cow, isotope tracer, liver metabolism, lipopolysaccharide challenge

\section{INTRODUCTION}

In periparturient cows, metabolic stress occurs as consequence of marked endocrine, neurologic, and immune system changes to divert the partitioning of nutrients from the fetus to the mammary gland for milk synthesis (Ingvartsen and Moyes, 2013). Moreover, the periparturient period is characterized by a period of immunosuppression, with reduced function of immune cells and development of oxidative stress that increases the risk of several diseases at this time (Sordillo et al., 2009). Although, the mechanisms are still not well understood, this transition period has been associated with an increased susceptibility to inflammatory diseases resulting in reduced animal health and economic outcome to the farmer (Mallard et al., 1998; Hammon et al., 2006). To meet the nutrient demands for lactation, most cows experience a period of negative energy balance (Ingvartsen, 2006), i.e., -1 wk before $\sim 3$ wk relative to parturition (Grummer, 1995). Under conditions of negative energy balance, elevated concentrations of circulating NEFA, BHBA, and lower glucose have been associated with an increased risk of digestive disorders, uterine problems (Ospina et al., 2010; Chapinal et al., 2011), and mastitis (Moyes et al., 2009b). From a global gene expression perspective, cows with severe negative energy balance have marked alterations in hepatic metabolism and pro-inflammatory response (Loor et al., 2005; McCarthy et al., 2010). 
In addition to its central role in metabolism, the liver secretes inflammatory mediators, i.e., acute phase proteins (serum amyloid A, SAA; haptoglobin, Hp) and cytokines [i.e., tumor necrosis factor- $\alpha$ (TNF- $\alpha)$ ], during inflammation (Jørgensen et al., 2012) and in response to intramammary Escherichia coli endotoxins such as LPS (Vels et al., 2009). Recent work suggests that the ability of the liver to metabolize FA is reduced and key genes associated with AA, glucose, lipid, and FA metabolic processes are downregulated after LPS challenge (Jiang et al., 2008). Reduced hepatic function may increase risk of subsequent disease, especially during early lactation (Drackley et al., 2005).

The relationship between hepatic metabolism, inflammation, and risk of subsequent disease is poorly understood. We have previously shown that glucose regulation is altered during the early response to mastitis (Moyes et al., 2009a, 2014). Furthermore, during early lactation when glucose availability is low, cows use AA derived from skeletal muscle degradation for energy and hepatic gluconeogenesis (Ingvartsen and Moyes, 2013). To our knowledge, no studies have examined whether increased AA or glucose supply improve hepatic function during inflammation.

The use of stable isotopes and GC-MS technologies in metabolic flux analysis provides unique measures of the dynamics of cellular metabolism and its regulation, which otherwise would not be accessible from static measurements of mRNA and protein expression or metabolite concentrations (Bequette et al., 2006; Griffin and Des Rosiers, 2009). However, a limited number of studies report using fluxomic technologies to evaluate the intermediary metabolism of nutrients and their utilization by tissues and cells (Bequette et al., 2006; El-Kadi et al., 2009). To our knowledge, no studies have examined how nutrients alter the inflammatory and metabolic responses of liver after LPS challenge in vitro and how stage of lactation may alter this response. Consequently, the objective of the current study was to characterize the effects of nutrient supply and LPS challenge on hepatic inflammatory and intermediate metabolism for cows in early and mid lactation by employing GC-MS with stable isotope tracers coupled with both protein- and transcription-level responses in vitro.

\section{MATERIALS AND METHODS}

\section{Cow Management and Biopsy Procedure}

The experimental protocol was approved by the Institutional Animal Care and Use Committee at the University of Maryland. Twelve multiparous HolsteinFriesian cows in early $(\mathrm{n}=6,12 \pm 4.2 \mathrm{DIM})$ and mid
( $\mathrm{n}=6,115 \pm 13.5$ DIM) lactation were used for this study. To be eligible, cows were free of clinical signs of disease, including normal heart and respiratory rate, with milk SCC $<200,000$ cells $/ \mathrm{mL}$ before biopsy. Cows were fed twice daily a standard TMR formulated to meet NRC (2001) requirements and were milked twice daily at 0700 and $1900 \mathrm{~h}$. Liver biopsies were performed on all cows after the morning milking and before the morning feeding $(\sim 0800 \mathrm{~h})$. Cows were housed and fed in free stalls and had access to water ad libitum. At the time of biopsy, $20 \mathrm{~mL}$ of blood was collected into vacutainer tubes without coagulant (Fisherbrand, Thermo Fisher Scientific Inc., Waltham, MA) via coccygeal venipuncture. After the biopsy procedure, cows were placed in tie-stalls for $10 \mathrm{~d}$ for daily monitoring. Blood was allowed to clot at room temperature for $\sim 2$ h. Tubes were centrifuged at $2,095 \times g$ for 15 min at $4^{\circ} \mathrm{C}$ (model 5810R, Eppendorf, Hauppauge, NY) and serum was frozen at $-20^{\circ} \mathrm{C}$ for metabolite analysis.

Liver tissue ( $\sim 1$ to $2 \mathrm{~g})$ was obtained under local anesthesia via puncture biopsy as described previously (Carlson et al., 2006). Liver tissue was placed in a 50$\mathrm{mL}$ tube containing ice-cold sterile PBS and transferred to the laboratory on ice $(\sim 2 \mathrm{~h})$.

\section{Liver Explant Treatments and Incubation}

Details of chemicals and reagents used are available in the Supplemental Material (http://dx.doi.org/10.3168/ jds.2014-9034). Treatments were prepared using Krebs ringer bicarbonate buffer (KRBB) as basal medium, as previously reported (Drackley et al., 1991; Carlson et al., 2006), for a final volume of $2.8 \mathrm{~mL}$ in 25 -mL flasks. Treatments were control (CTL; KRBB only), pyruvate (PYR; $1 \mathrm{~m} M$ unlabeled pyruvate and $1 \mathrm{mM}\left[{ }^{13} \mathrm{C}_{3}\right]$ pyruvate), pyruvate + propionate $(\mathbf{P Y R}+\mathbf{P R O} ; 1 \mathrm{mM}$ unlabeled pyruvate, $1 \mathrm{mM}\left[{ }^{13} \mathrm{C}_{3}\right]$ pyruvate, and $2 \mathrm{mM}$ sodium propionate), and pyruvate $+\mathrm{AA}(\mathbf{P Y R}+\mathbf{A A}$; $1 \mathrm{~m} M$ unlabeled pyruvate, $1 \mathrm{~m} M\left[{ }^{13} \mathrm{C}_{3}\right]$ pyruvate, and $2 \mathrm{~m} M$ AA solution). Liver tissue $(\sim 20 \mathrm{mg})$ was sliced using a Krumdieck automated tissue slicer (Alabama Research and Development, Munford, AL). Each flask $(25 \mathrm{~mL})$ contained 40 to $60 \mathrm{mg}$ of tissue. Treatments were run in duplicate. Flasks were transferred to a sterile hood, and $200 \mu \mathrm{L}$ of PBS or LPS $(3 \mu \mathrm{g} / \mathrm{mL}$ working solution, to provide $0.2 \mu \mathrm{g}$ of LPS $/ \mathrm{mL}$ of total culture medium, L055, Sigma Aldrich) was added. Flasks were gassed with $95 \mathrm{CO}_{2}: 5 \mathrm{O}_{2}$ for $10 \mathrm{~s}$ and immediately sealed with a rubber septum. Flasks were incubated in a shaking water bath (VWR International, Philadelphia, PA) at $37^{\circ} \mathrm{C}$ for $2 \mathrm{~h}$. A pilot study revealed that 2 -h incubation time was sufficient to establish metabolic equilibrium of Krebs cycle intermediates for GC-MS analyses described below. After incubation, 
the medium was stored at $-80^{\circ} \mathrm{C}$ for further analyses. Liver slices were washed with ice-cold PBS and stored at $-80^{\circ} \mathrm{C}$ until GC-MS and gene expression analyses.

\section{Analysis of Metabolites and Proteins in Serum and Liver Explant Media}

NEFA and BHBA Assays. Commercially available kits were used to measure concentrations of NEFA (NEFA-HR kit; Wako Diagnostics Inc., Richmond, VA) and BHBA (Stanbio Laboratories, Boerne, TX). Serum samples per each assay were run on a single plate following the manufacturer's instructions adjusted for a 96-well plate. The intraassay CV were 1.5 and $5.9 \%$ for NEFA and BHBA, respectively.

Glucose Assay. Serum and spent media were analyzed by a glucose oxidase methodology using a commercially available kit (Stanbio Laboratories) using the manufacturer's instructions adjusted for a 96-well plate. All treatments performed for a given cow were run on the same plate. The intra- and interassay CV were 3.3 and $5.6 \%$, respectively.

$\boldsymbol{T N F - \alpha}$ Assay. Spent media were analyzed for concentrations of TNF- $\alpha$ using a bovine-TNF- $\alpha$ commercially available kit (VetSet ELISA Development Kit, Kingfisher Biotech Inc., St. Paul, MN) following the manufacturer's instructions. Standards were prepared with $4 \%$ BSA in PBS, and samples were diluted to $90 \%$ concentration with the same standard diluents (4\% BSA in PBS). Samples were run in duplicate and all treatments performed for a given cow were run on the same plate. The intra- and interassay $\mathrm{CV}$ were 1.5 and $7.0 \%$, respectively.

Haptoglobin Assay. Serum and media were analyzed using a bovine Hp commercially available kit (Stanbio Laboratories, Boerne, TX). Serum samples were run following the manufacturer's instructions with minor modifications for medium samples only. Briefly, $10 \times$ standard diluent was diluted to $1 \times$ concentration using KRBB for standard preparation. Medium samples were diluted to $90 \%$ concentration with $10 \times$ standard diluent. All samples were run in duplicate, and all treatments performed for a given cow were run on the same plate. The intra- and interassay CV were 2.8 and $5.1 \%$, respectively.

\section{RNA Isolation, cDNA Synthesis, and Quantitative Reverse-Transcription PCR}

Specific details for total RNA isolation and quality evaluation, cDNA synthesis, primer selection and efficiency evaluation, and quantitative reverse-transcription PCR (qPCR) analysis are found in the Supplemental Material (http://dx.doi.org/10.3168/jds.2014-9034).
Purity of extracted RNA was calculated by absorbance ratio of 260/280 measured using a NanoVue Plus (GE Healthcare, Piscataway, NJ) and averaged 1.98 (range 1.75 to 2.08). Integrity of RNA was measured by the RNA quality indicator number using an Experion bioanalyzer (Bio-Rad Laboratories Inc., Hercules, CA; Supplemental Material, http://dx.doi.org/10.3168/ jds.2014-9034). Primer sequences and accession number are presented in Supplemental Table S1 (http://dx.doi. org/10.3168/jds.2014-9034). Primer and qPCR validation detailing the slope, intercept, $\mathrm{R}^{2}$, and efficiency of the dilution curve as well as the range of quantification cycles (Cq) and the median for each gene across all samples are found in Supplemental Table S2 (http:// dx.doi.org/10.3168/jds.2014-9034). The Cq from target genes were normalized by the geometric mean of 2 (LRP10 and HPCAL1) out of 4 candidate target genes (ACTB, GAPDH, LRP10, and HPCAL1) that were previously verified as suitable reference genes in bovine tissue (Janovick-Guretzky et al., 2007; Kadegowda et al., 2009; Saremi et al., 2012). These 2 reference genes were selected based on their lower $\mathrm{M}$ value (measure of reference gene stability; lowest value, greater stability) as recommended by the genorm analysis ( $\mathrm{M}<$ 0.50) using the Biogazelle $\mathrm{q}^{+}$software (Biogazelle NV, Zwijnaarde, Belgium) and based on the work of Vandesompele et al. (2002).

The qPCR results, given that $\mathrm{Cq}$ negatively reflects the expression of a target gene (lower $\mathrm{Cq}$ translates to greater gene expression), were analyzed using the $2^{-\Delta \mathrm{Cq}}$ method (Livak and Schmittgen, 2001). Briefly, the Cq of each target gene was calculated and normalized by the geometric mean of the 2 selected reference genes to generate a $\Delta \mathrm{Cq}$ value. The $\Delta \mathrm{Cq}$ values without transformation were subjected to statistical analysis. General description of the main biological function of the genes of interest can be found in Supplemental Table S3 (http://dx.doi.org/10.3168/jds.2014-9034).

\section{GC-MS Analysis for Krebs Cycle Intermediates in Liver Explant and Enrichment Calculations}

Liver was thawed on ice, and $1 \mathrm{~mL}$ of ice-cold sulfosalicylic acid (10\%, wt:vol) was added. Tissue was homogenized with a $5 \mathrm{~mm} \times 75 \mathrm{~mm}$ probe (VWR International). Homogenate product was centrifuged at $13,000 \times g$ for $10 \mathrm{~min}$ at room temperature. The deproteinized acid supernatant was applied to a cationexchange resin (AG 50W-X8, 100-200 mesh, Bio-Rad Laboratories Inc.). Amino acids and lactate were eluted with $2 \mathrm{~mL}$ of $2 \mathrm{M} \mathrm{NH}_{4} \mathrm{OH}$ followed by $1 \mathrm{~mL}$ of water. Eluate was frozen and then lyophilized to dryness. Amino acids were converted to tert-butyldimethylsilyl using a $1: 1(\mathrm{vol} / \mathrm{vol})$ mixture of $N$-methyl- $N$-[tert- 
butyldimethyl-silyl]trifluoroacetimide (containing $1 \%$ tert-tert-butyldimethylchlorosilane, United Chemical Technologies Inc., Bristol, PA) and dimethylformamide (Thermo Scientific, Rockford, IL). After heating via a microwave ( $200 \mathrm{~W}$ for $2 \mathrm{~min}$ ), the AA tert-butyldimethyl-silyl derivatives were separated by GC-MS (HP 5973N Mass Selective Detector, Agilent, Palo Alto, CA). Fragment ions containing all carbons of an analyte (alanine, aspartate, glutamate) were monitored under electron impact mode. Normalized crude ion abundances of the enriched analytes were corrected for the measured natural abundance of stable isotopes present in the original molecule and that contributed by the derivative using the matrix approach of (Brauman, 1966).

Corrected enrichment precursors, intermediates, and products are reported on tracer:tracee ratios in the form of mol $\left[{ }^{13} \mathrm{C}_{3}\right]$ pyruvate $(\mathrm{M} n)$ per $100 \mathrm{~mol}{ }^{12} \mathrm{C}$ analyte (M0), where $n$ equals the number of ${ }^{13} \mathrm{C}$ labeled carbons in the analyte, e.g., [M1], [M2], and [M3] alanine (Supplemental Table S4; http://dx.doi. org/10.3168/jds.2014-9034). The calculation of the enrichment of Krebs cycle intermediates was based on the assumption that the labeling of alanine, aspartate, and glutamate is a direct reflection of the labeling of their respective transamination partners pyruvate, oxaloacetate, and $\alpha$-ketoglutarate, respectively (Wykes et al., 1998). Hence, metabolic fate of $\left[{ }^{13} \mathrm{C}_{3}\right]$ pyruvate via Krebs cycle results in distinctive ${ }^{13} \mathrm{C}$-labeling patterns of intermediary metabolites and provide information on the contributions of pyruvate to intermediary fluxes and the activity of the enzymatic pathways through which the ${ }^{13} \mathrm{C}$-intermediates transverse (Wykes et al., 1998). Under steady-state conditions, common fates of pyruvate are acetyl-CoA, lactate, and oxaloacetate. Via pyruvate carboxylase (PC), [M3]pyruvate introduces the [M3] oxaloacetate isotopomer into the Krebs cycle, which subsequently reaches a metabolic equilibrium with its transamination partner [M3]aspartate (Supplemental Figure S1; http://dx.doi.org/10.3168/ jds.2014-9034). Similarly, [M3]oxaloacetate eventually leads to formation of [M3] $\alpha$-ketoglutarate, which is in metabolic equilibrium with its transamination partner [M3]glutamate. Alternatively, via pyruvate dehydrogenase (PDH), the [M3]pyruvate isotopomer can be metabolized to yield [M2]acetyl-CoA and hence [M2] $\alpha$-ketoglutarate and its corresponding transamination partner [M2]glutamate. However, the [M2]glutamate also arises as a consequence of the metabolic cycling between oxaloacetate and fumarate. This metabolic cycle yields an equilibrium mixture of [M3] oxaloacetate [C1-C3] and [M3] oxaloacetate $_{[\mathrm{C} 2-\mathrm{C} 4]}$. At the decarboxylation step between citrate and $\alpha$-ketoglutarate, however, carbon 1 of oxaloacetate is lost. As a result, half of [M3]oxalo- acetate contributes to [M2] $\alpha$-ketoglutarate enrichment on the first turn, which is defined by the tracer:tracee ratio of [M3]glutamate (Pascual et al., 1998). On the second turn, [M3] $\alpha$-ketoglutarate leads to an equilibrium mixture of [M2] oxaloacetate $_{[\mathrm{C} 1-\mathrm{C} 2]}$ and [M2] oxaloacetate $_{[\mathrm{C3}-\mathrm{C} 4]}$, of which only [M2] oxaloacetate $_{[\mathrm{C} 3-\mathrm{C} 4]}$ contributes to the $[\mathrm{M} 2] \alpha$-ketoglutarate enrichment, which is defined by half of [M3]glutamate. Therefore, the [M2] acetyl-CoA enrichment was calculated as

$$
\text { [M2]glutamate }-1.5 \times[\text { M3]glutamate }
$$

The fractional contribution of $\left[{ }^{13} \mathrm{C}_{3}\right]$ pyruvate pool to [M2] acetyl-CoA synthesis was calculated as Pascual et al. (1998), considering that only half of the equilibrium mixture of [M2]alanine contributes to the [M2]acetylCoA enrichment:

$$
\frac{[\mathrm{M} 2] \text { acetyl }-\mathrm{CoA}}{(0.5 \times[\mathrm{M} 2] \text { alanine }+[\mathrm{M} 3] \text { alanine })} .
$$

The fractional contribution of the $\left[{ }^{13} \mathrm{C}_{3}\right]$ pyruvate pool to [M3] oxaloacetate synthesis was calculated as a direct ratio according to Wykes et al. (1998):

$$
\frac{[\mathrm{M} 3] \text { aspartate }}{\text { [M3] alanine }} \text {. }
$$

A crude activity of phosphoenolpyruvate carboxykinase (PEPCK) can be estimated from the appearance of [M1] and [M2]alanine isotopomers given that these isotopomers can only arise from the Krebs cycle via PEPCK activity. Therefore, relative activity of PEPCK was calculated as

$$
\frac{[\mathrm{M} 1] \text { alanine }+[\mathrm{M} 2] \text { alanine }}{[\mathrm{M} 3] \text { alanine }} .
$$

The relative activity of $\mathrm{PDH}$ versus $\mathrm{PC}$ can be estimated from the synthesis of [M2]acetyl-CoA coming from the pool of $\left[{ }^{13} \mathrm{C}_{3}\right]$ pyruvate respect to the enrichment of [M3]glutamate coming from the equilibrium reaction of [M3]oxaloacetate and [M3] $\alpha$-ketoglutarate:

$$
\frac{[\mathrm{M} 2] \text { acetyl }-\mathrm{CoA}}{[\mathrm{M} 3] \text { glutamate }} \text {. }
$$

\section{Statistical Analysis}

The PROC MIXED procedure of SAS (SAS/STAT version 9.2; SAS Institute Inc., Cary, NC) was used for statistical analysis. For analysis of metabolites in 
serum, the class variables included cow and stage of lactation. For measures of gene expression and concentrations of glucose, TNF- $\alpha$, and $\mathrm{Hp}$ in media, the data were analyzed using a randomized block (stage of lactation) design in a factorial arrangement $4 \times 2$ with factors including 4 different nutrients (i.e., CTL, PYR, PYR+PRO, PYR+AA) and 2 doses of LPS (i.e., 0 and $0.2 \mu \mathrm{g} / \mathrm{mL}$ of culture media). To compare the data from the nutrient flux analysis with gene expression, data from both the nutrient flux and gene expression were also analyzed in a factorial arrangement $3 \times 2$ with 3 different nutrients and 2 doses of LPS. For both models, the class variables included cow, nutrient, LPS, and stage of lactation (i.e., early and mid lactation). Separation of LSM and individual comparisons for significant effects were performed using the PDIFF statement in SAS. For statistical models, the 3-way interaction and the interaction of stage of lactation $\times$ LPS were not significant, and therefore were not included in the final model. For both statistical models, to determine the effect of class variables on liver response the model was as follows:

$$
\begin{gathered}
\mathrm{Y}_{\mathrm{ijkl}=\mu}+\mathrm{S}_{\mathrm{i}}+\mathrm{C}(\mathrm{S})_{\mathrm{ij}}+\mathrm{N}_{\mathrm{k}}+\mathrm{NS}_{\mathrm{ik}} \\
+\mathrm{L}_{\mathrm{l}}+\mathrm{NL}_{\mathrm{kl}}+\varepsilon_{\mathrm{ijkl}} .
\end{gathered}
$$

where $Y_{i j k l}$ is the observation, $\mu$ is overall mean, $S_{i}$ is the fixed effect of stage of lactation $\mathrm{i}, \mathrm{C}(\mathrm{S})_{\mathrm{ij}}$ is the random effect of cow $\mathrm{j}$ within stage of lactation $\mathrm{i}, \mathrm{N}_{\mathrm{k}}$ is the fixed effect of nutrient $\mathrm{k}, \mathrm{NS}_{\mathrm{ik}}$ is interaction of nutrient $\times$ stage of lactation, $L_{1}$ is the fixed effect of LPS dose l, $\mathrm{NL}_{\mathrm{kl}}$ is the interaction of nutrient $\times$ LPS, and $\varepsilon_{\mathrm{ijkl}}$ is the residual error. For both models, the degrees of freedom were estimated with the Kenward-Roger specification in the model statement. The data are presented as LSM and pooled SEM. Statistical differences were declared as significant if $P \leq 0.05$ with a trend toward significance if $0.05<P \leq 0.10$. Fold changes were calculated to aid on the interpretation of gene expression. Briefly, $\operatorname{LSM}(\Delta \mathrm{Cq})$ of a factor of interest was subtracted from the LSM $(\Delta \mathrm{Cq})$ of other referential factor to generate the $\Delta \Delta \mathrm{Cq}$ value, which was linearized to a fold change value with the formula $2^{-\Delta \Delta \mathrm{Cq}}$ (Livak and Schmittgen, 2001).

\section{RESULTS}

\section{Metabolic Status of Experimental Cows}

Concentrations of serum BHBA were $\sim 5$ times greater $(P<0.01)$ in early $(8.84 \mathrm{mg} / \mathrm{dL})$ than cows in mid lactation $(1.73 \mathrm{mg} / \mathrm{dL}$, Table 1$)$. Similarly, concentrations of serum NEFA were approximately 3 times
Table 1. Serum concentrations of BHBA, NEFA, glucose, and haptoglobin for Holstein cows in early $(n=6)$ or mid $(n=6)$ lactation before liver tissue collection

\begin{tabular}{lcccr}
\hline & \multicolumn{2}{c}{ Stage of lactation } & & \\
\cline { 2 - 3 } Metabolite $^{1}$ & Early & Mid & \multirow{2}{*}{ SEM } & $P$-value \\
\hline BHBA, mg/dL & 8.84 & 1.73 & 1.03 & $<0.01$ \\
NEFA, mEq/L & 1.35 & 0.40 & 0.22 & 0.01 \\
Glucose, mg/dL & 55.4 & 66.2 & 4.1 & 0.09 \\
Haptoglobin, mg/L & 62.6 & 4.6 & 29.4 & 0.19 \\
\hline
\end{tabular}

greater $(P=0.01)$ for cows in early lactation, whereas glucose tended $(P=0.09)$ to be slightly lower for cows in early $(55.4 \mathrm{mg} / \mathrm{dL})$ than mid lactation $(66.2 \mathrm{mg} /$ $\mathrm{dL})$. Concentrations of serum $\mathrm{Hp}$ did not differ with stage of lactation (62.6 vs. $4.6 \mathrm{mg} / \mathrm{L}$, for cows in early and mid lactation, respectively).

\section{Glucose, TNF- $\alpha$, and Haptoglobin Concentrations in Media from Liver Explants}

After $2 \mathrm{~h}$ of incubation, the concentration of glucose in the spent medium did not differ due to nutrients $(142.7,140.9,142.2$, and $141.2 \mathrm{mg} / \mathrm{dL}$ for CTL, PYR, $\mathrm{PYR}+\mathrm{PRO}$, and PYR+AA, respectively, Table 2) due to LPS challenge or stage of lactation. Concentrations of TNF- $\alpha$ in medium were altered by nutrient $(P<$ $0.01)$ and by LPS challenge $(P<0.01)$ but not by stage of lactation. A nutrient $\times$ LPS interaction was also observed ( $P=0.01$, Figure 1$)$ where TNF- $\alpha$ concentration was greater for CTL, PYR, and PYR+AA than PYR + PRO for liver incubated with LPS only. Medium concentrations of Hp after $2 \mathrm{~h}$ of incubation were not affected by nutrients $(12.5,11.9,11.2$, and $11.5 \mathrm{mg} /$ $\mathrm{dL}$ for CTL, PYR, PYR+PRO, and PYR+AA, respectively) due to LPS or stage of lactation.

\section{Gene Expression}

The expression of PPARA, PCK1, HMGCS2, and GOT2 for liver explants was not altered by nutrient, LPS, or stage of lactation in vitro (Table 3). Expression of all 3 immune-related genes: TNFA (2.31-fold change, $P<0.01), H P(1.26$-fold change, $P=0.05)$, and $S A A 2$ (1.26-fold change, $P=0.10)$ were upregulated with LPS challenge but were not affected by stage of lactation or by interactions.

Expression of TNFA tended $(P=0.08)$ to be altered by nutrient. Liver slices incubated with PYR $+\mathrm{PRO}$ observed a downregulation of TNFA compared with CTL (-1.44-fold change) or with PYR (-1.40-fold change) but was similar to that with PYR+AA. Nutrient did not affect the expression of $H P$, whereas the expres- 
sion of SAA2 $(P=0.05)$ was altered by nutrient where PYR or PYR+AA induced an upregulation of $S A A 2$ compared with CTL.

Expression of gluconeogenic enzymes G6PC $(P=$ $0.01)$ and $P C(P=0.07)$ were altered by nutrient. Incubation with $\mathrm{PYR}+\mathrm{PRO}$ downregulated $P C$ expression compared with PYR (-1.58-fold change) or with PYR+AA (-1.51-fold change), whereas the expression was similar compared with CTL. Expression of $G 6 P C$ was upregulated in liver slices incubated with PYR (1.74-fold change) or with PYR+AA (1.45-fold change) compared with CTL. The expression of G6PC was downregulated in liver slices incubated with PYR $+\mathrm{PRO}$ compared with PYR ( -1.45 -fold change) only but was similar when compared with CTL or with PYR+AA. In addition, expression of $P C$ was upregulated for liver slices incubated with LPS (1.39-fold change, $P=0.03$ ) versus no LPS and from cows in early lactation (3.35fold change, $P=0.01)$ when compared with mid lactation. Expression of $P D H A$ was upregulated $(P=0.02)$ in liver incubated with either PYR (1.26-fold change) or PYR+AA (1.37 fold change) compared with CTL, whereas $P D H A$ expression did not differ among liver explants incubated with PYR, PYR+PRO, or PYR+AA.

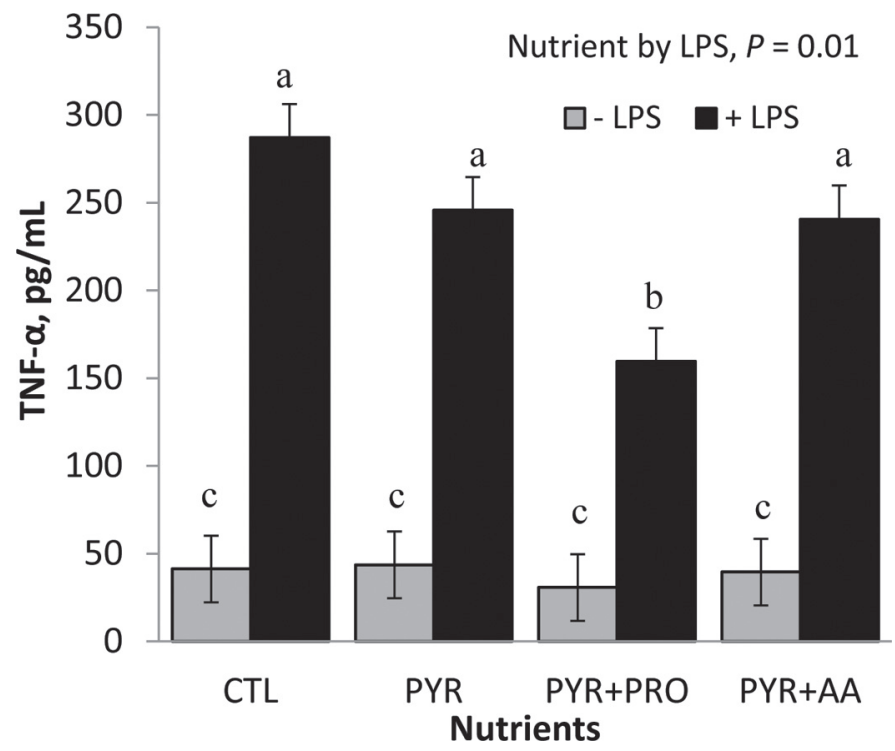

Figure 1. Concentration of tumor necrosis factor $\alpha(\mathrm{TNF}-\alpha)$ from liver explants from Holstein cows $(\mathrm{n}=12)$ incubated with either pyruvate (PYR; $1 \mathrm{~m} M$ unlabeled pyruvate and $1 \mathrm{~m} M{ }^{13} \mathrm{C}_{3}$ pyruvate), pyruvate + propionate (PYR+PRO; $1 \mathrm{~m} M$ unlabeled pyruvate, 1 $\mathrm{m} M{ }^{13} \mathrm{C}_{3}$ pyruvate, and $2 \mathrm{~m} M$ sodium propionate), or pyruvate $+\mathrm{AA}$ (PYR+AA; $1 \mathrm{~m} M$ unlabeled pyruvate, $1 \mathrm{~m} M{ }^{13} \mathrm{C}_{3}$ pyruvate, and $2 \mathrm{~m} M$ AA solution) and with $(0.2 \mu \mathrm{g} / \mathrm{mL}$ of culture medium) or without $(0.0$ $\mu \mathrm{g} / \mathrm{mL}$ of culture medium) LPS for $2 \mathrm{~h}$ in vitro. Means with different letters $(\mathrm{a}-\mathrm{c})$ differ $(P \leq 0.05)$. CTL $=$ control. Error bars represent treatment SEM.

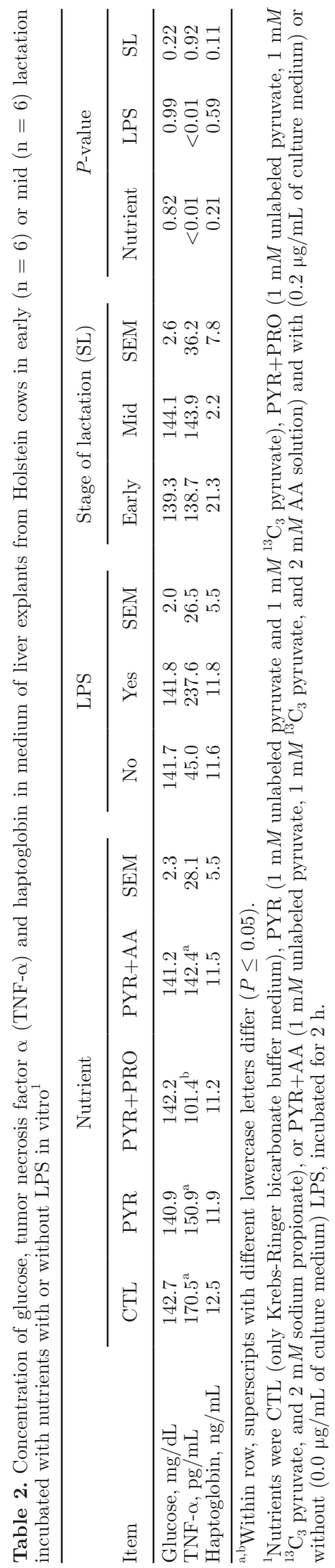

Journal of Dairy Science Vol. 98 No. 10, 2015 


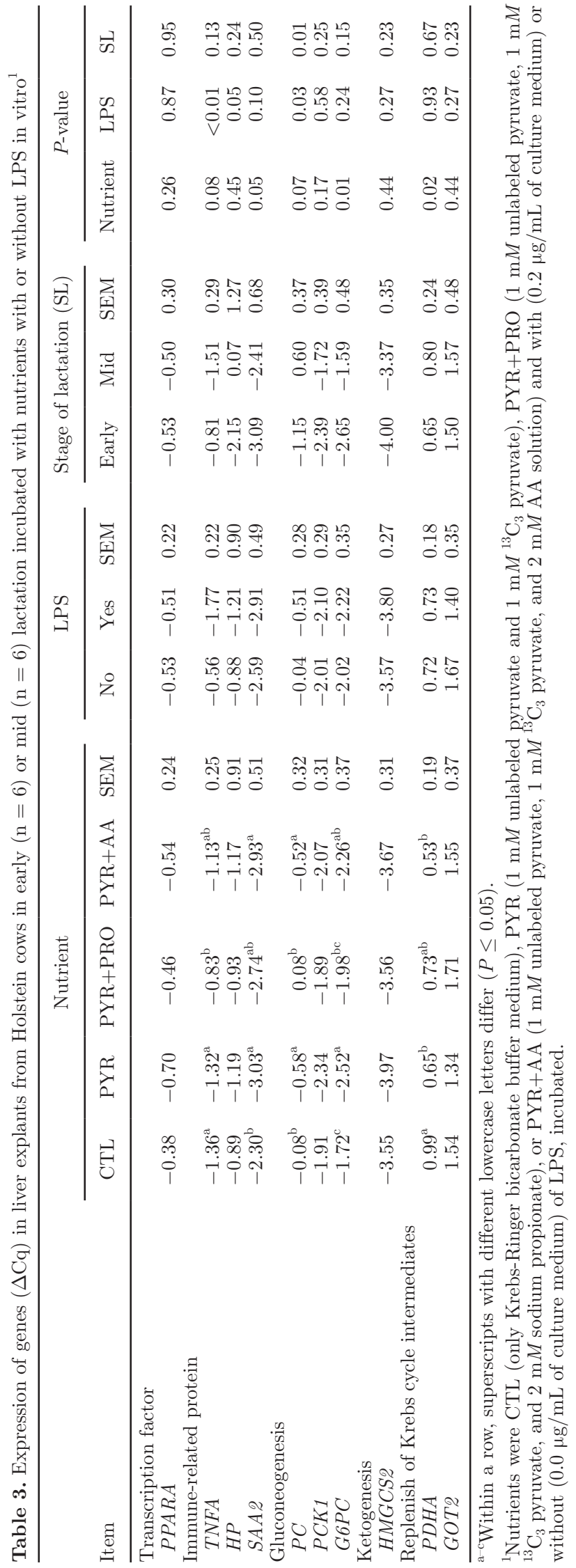

\section{Enrichment of NEAA and Acetyl-CoA from $\left[{ }^{13} C_{3}\right]$ Pyruvate}

In vitro incubation of liver explants with $\left[{ }^{13} \mathrm{C}_{3}\right]$ pyruvate resulted in significant enrichment of AA in equilibrium with intermediary compounds in the Krebs cycle. Table 4 shows the enrichment of [M1], [M2], and [M3] alanine, aspartate, and glutamate, and [M2] acetyl CoA after incubation of liver slices from cows in early and mid lactation with PYR, PYR+AA, or PYR+PRO with or without LPS in vitro, and Table 5 shows the effect of nutrient $\times$ stage of lactation interaction found for [M2]alanine, [M1] and [M2] aspartate, and [M1] and [M3]glutamate. Regardless of any effect, [M3]alanine and [M3] aspartate were the most enriched isotopomers with an average enrichment of 33.6 and $27.8 \mathrm{~mol}$ of tracer/100 mol of tracee, respectively.

All 3 alanine isotopomers were affected by nutrient $(P \leq 0.03)$ where liver slices incubated with PYR + PRO had lower enrichment of [M1] and [M3] isotopomers compared with PYR and PYR+AA (Table 4). The [M2]alanine enrichment was lower for liver slices incubated PYR+PRO and PYR+AA compared with PYR. Lipopolysaccharide challenge reduced the enrichment of [M1] and [M2]alanine. The enrichment of [M3]alanine was lower $(P=0.03)$ in early lactation cows. The nutrient $\times$ stage of lactation interaction altered the enrichment of [M2]alanine (Table 5) where the enrichment of [M2] alanine was greater in liver slices from cows in mid lactation incubated with PYR than PYR + PRO and PYR+AA. Nutrient had no effect on the enrichment of [M2]alanine for cows in early lactation. No other interactions altered the enrichment of all 3 alanine isotopomers.

Regardless of LPS and stage of lactation, enrichment of [M1] and [M2] aspartate was lower $(P<0.01)$ for liver slices incubated with PYR+AA compared with PYR or PYR+PRO (Table 4). Enrichment of [M3] aspartate for liver slices incubated with either PYR+PRO or PYR+AA was lower $(P<0.01)$ compared with PYR. The LPS challenge tended $(P=0.10)$ to reduce the enrichment of [M1]aspartate. With regard to the interaction of nutrient $\times$ stage of lactation (Table 5), enrichment of [M1] and [M2] aspartate was greatest for liver slices from cows in mid lactation incubated with PYR and lowest with PYR+AA for cows in early lactation. An interaction of nutrient $\times$ LPS was observed where LPS challenge reduced the enrichment of [M1] aspartate in liver slices incubated with $\mathrm{PYR}+\mathrm{PRO}$ with LPS compared with PYR+PRO without LPS. No other interactions altered the enrichment of aspartate isotopomers.

The greatest $(P<0.01)$ enrichment of all 3 glutamate isotopomers was observed for liver slices incubated with 


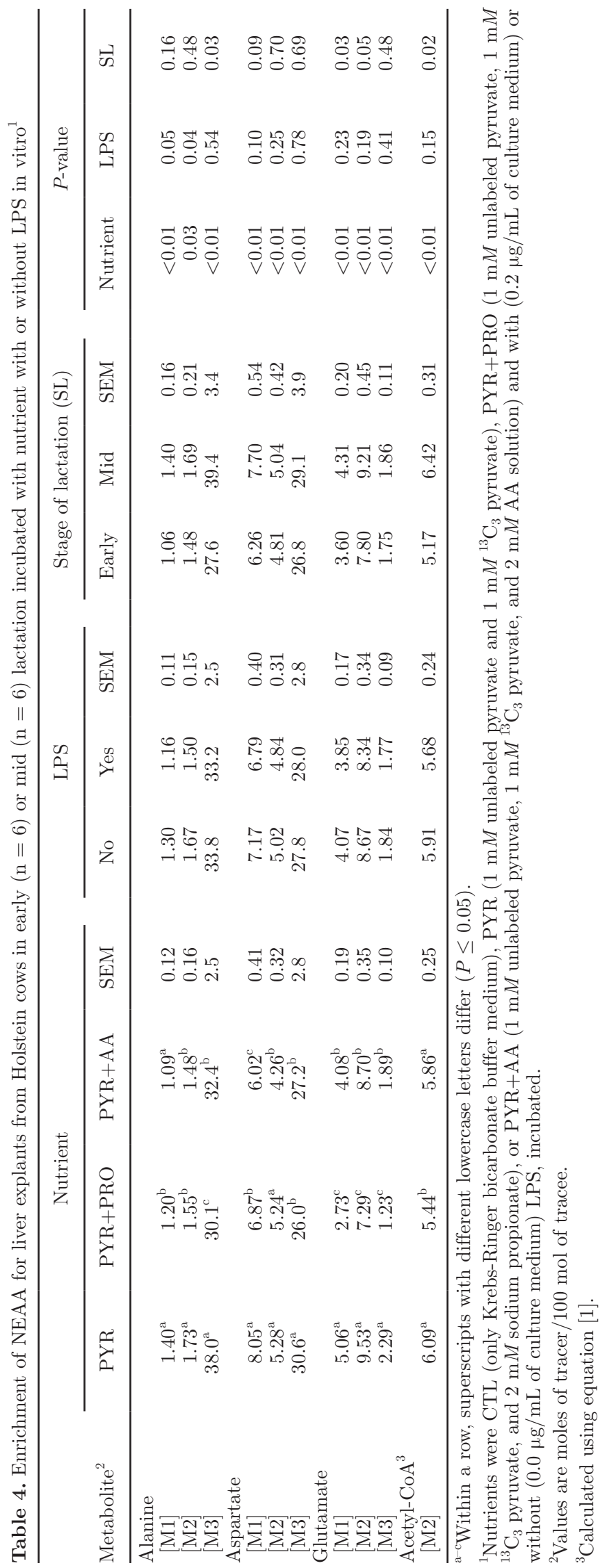

PYR, whereas the lowest enrichment was observed for liver slices incubated with PYR+PRO (Table 4). The nutrient $\times$ stage of lactation interaction (Table 5) revealed that [M1] and [M3]glutamate were greatest in liver slices incubated with PYR for cows in mid lactation.

The calculated enrichment of [M2]acetyl-CoA was lower $(P<0.01)$ for liver slices incubated with $\mathrm{PYR}+\mathrm{PRO}$ compared with PYR or PYR+AA, regardless of stage of lactation and LPS challenge (Table 4). Cows in mid lactation had a greater $(P=0.02)$ enrichment of [M2]acetyl-CoA than cows in early lactation.

\section{Contribution of $\left[{ }^{13} C_{3}\right]$ Pyruvate to Acetyl-CoA and Oxaloacetate Fluxes}

The contribution of $\left[{ }^{13} \mathrm{C}_{3}\right]$ pyruvate to the acetyl$\mathrm{CoA}$ and oxaloacetate fluxes (Table 6) into the Krebs cycle was altered by nutrient. Liver incubated with $\mathrm{PYR}+\mathrm{PRO}$ or $\mathrm{PYR}+\mathrm{AA}$ had greater $(P=0.04)$ acetyl-CoA flux compared with PYR, whereas oxaloacetate flux was greater $(P=0.04)$ with $\mathrm{PYR}+\mathrm{PRO}$ compared with PYR. Neither LPS challenge nor with the LPS $\times$ nutrient interaction altered the flux of these Krebs cycle intermediates. However, stage of lactation tended $(P=0.09)$ to alter the oxaloacetate flux where cows in early lactation $(98.1 \%)$ tended to have greater flux of pyruvate to oxaloacetate compared with cows in mid lactation (74.0\%). The most pronounced effect of stage of lactation was observed in liver incubated with PYR+AA (nutrient $\times$ stage of lactation, $P=0.04$, Figure 2A) than PYR or PYR+PRO.

\section{Relative Enzymatic Activity}

Supplementation of nutrients altered the relative activity of gluconeogenic enzymes. An increase $(P<0.01)$ in the relative activity of $\mathrm{PDH}$ versus $\mathrm{PC}$ was observed for liver slices incubated with PYR + PRO, followed by PYR+AA, whereas PYR induced the lowest activity (4.64, 3.19, and 2.68, respectively, Table 6$)$. The relative activity of PEPCK was greater $(P=0.03)$ for liver explants incubated with PYR+PRO compared with PYR+AA (9.66 vs. 8.42) or with PYR+AA (9.66 vs. $8.08)$. In vitro challenge with LPS tended $(P=0.09)$ to decrease the activity of PEPCK but not that of PDH versus $\mathrm{PC}$, and no effect of the interaction of LPS $\times$ nutrient was observed for both enzymatic activities.

Cows in early lactation had lower $(P<0.01)$ relative activity of PDH versus PC (3.17 vs. 3.87) compared with cows in mid lactation. Figure $2 \mathrm{~B}$ shows the relative activity of PDH versus PC for liver explants incubated with different nutrients for cows in early and mid lactation. Results show that the relative activity of $\mathrm{PDH}$ 
versus $\mathrm{PC}$ in liver slices incubated with $\mathrm{PYR}+\mathrm{PRO}$ or PYR+AA for cows in mid lactation was more marked compared with cows in early lactation. For cows in mid lactation, incubation of liver slices with $\mathrm{PYR}+\mathrm{PRO}$ induced the greatest $\mathrm{PDH}$ versus $\mathrm{PC}$ activity.

\section{DISCUSSION}

As expected, cows in early lactation had greater serum BHBA and NEFA than cows in mid lactation (Bionaz et al., 2007; Qu et al., 2014). Moreover, cows in early lactation tended to have lower concentrations of glucose compared with mid-lactation cows. Therefore, the liver explants of these cows reflect the metabolic differences that normally are observed between cows in early when compared with later lactation (Ingvartsen and Moyes, 2013). In addition, increased concentrations of $\mathrm{Hp}$, even in clinically healthy cows $(>0.47$ or $\geq 1.0$ $\mathrm{g} / \mathrm{L}$ ), produced by the liver under inflammatory states, has been associated with diseases such as mastitis (Eckersall et al., 2001) and metritis (Huzzey et al., 2009). Coupled with our other health indicators, results indicate that all cows were clinically healthy before biopsy for this study.

\section{LPS Induced a Pro-Inflammatory State and Affected the Acute Phase and Metabolic Responses}

The LPS dose used in the current study was able to mount a pro-inflammatory condition, as confirmed by the upregulation of the TNFA, HP, and SAA2 in liver explants coupled with increased concentrations of TNF- $\alpha$ protein in the media when compared with liver explants incubated without LPS. Inflammatory LPS challenge upregulated the expression of $H P$, but this effect was not observed at the protein level. The genes $H P$ and $S A A 2$ code for 2 common acute phase proteins produced in the liver during the inflammatory response (Ceciliani et al., 2012). Although statically significant, the fold change was quite small (1.26) regarding the expression of $H P$ and $S A A 2$ after LPS challenge in vitro. Coupled with a short duration of incubation (i.e., $2 \mathrm{~h}$ ), biological significance is questionable.

For this study, inflammatory LPS challenge altered hepatic metabolism in vitro. At the transcription level, we observed an upregulation of $P C$ that codes for the key gluconeogenic enzyme responsible for the synthesis of oxaloacetate from pyruvate (Greenfield et al., 2000). However, G6PC and PCK1 were not altered by LPS challenge, indicating that LPS challenge in vitro had minimal effects on hepatic gluconeogenesis at the transcription level. In addition, neither the flux of pyruvate to oxaloacetate nor the enzymatic activity of $\mathrm{PDH}$ versus PC nor glucose concentration in media were altered during inflammatory challenge with LPS. However, enrichment of [M1] and [M2] alanine were reduced during LPS challenge, indicating that the synthesis of glucose was impaired during inflammation, as confirmed by a tendency for reduced PEPCK activity. Overall, our results suggest that LPS elicited a pro-inflammatory response and may alter hepatic gluconeogenesis for lactating cows.

Our results provide support for altered hepatic gluconeogenesis after inflammatory challenge in vivo. Waldron et al. $(2003,2006)$ challenged lactating cows with intravenous or intramammary infusion of LPS in vivo and reported increased gluconeogenesis, as measured by an increased glucose appearance in circulation, and increased hepatic capacity to convert propionate in glucose. However, an in vivo challenge with subcuta-

Table 5. Enrichment of NEAA for liver explants from Holstein cows in early $(\mathrm{n}=6)$ or mid $(\mathrm{n}=6)$ lactation incubated with nutrients with or without LPS in vitro

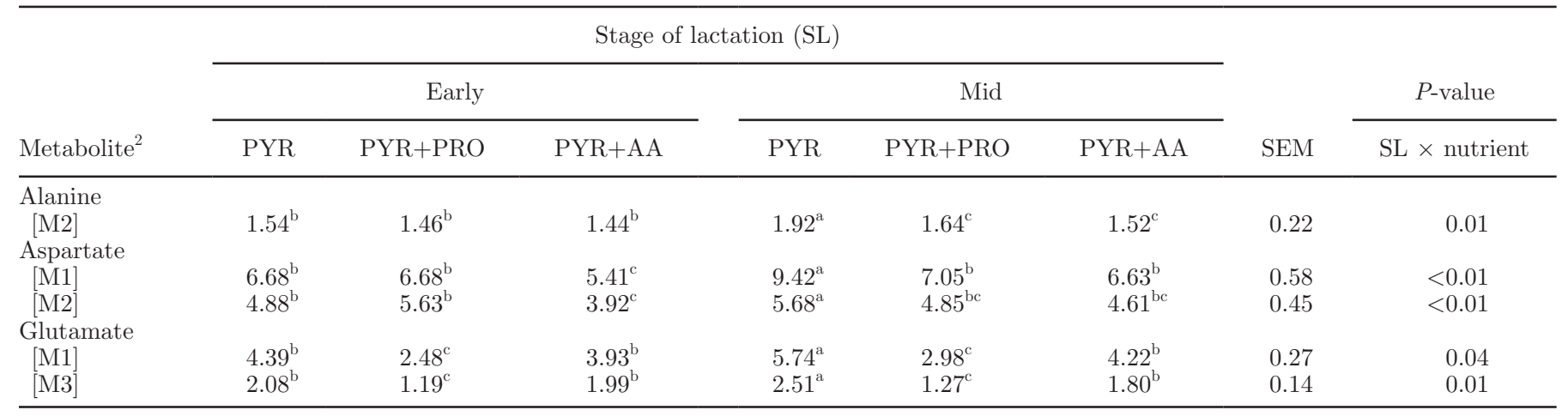

${ }^{\mathrm{a}-\mathrm{c}}$ Within row, superscripts with different lowercase letters differ $(P \leq 0.05)$.

${ }^{1}$ Nutrients were CTL (only Krebs-Ringer bicarbonate buffer medium), PYR ( $1 \mathrm{~m} M$ unlabeled pyruvate and $1 \mathrm{~m} M{ }^{13} \mathrm{C}_{3}$ pyruvate), PYR+PRO (1 $\mathrm{m} M$ unlabeled pyruvate, $1 \mathrm{~m} M{ }^{13} \mathrm{C}_{3}$ pyruvate, and $2 \mathrm{~m} M$ sodium propionate), or PYR+AA ( $1 \mathrm{~m} M$ unlabeled pyruvate, $1 \mathrm{~m} M{ }^{13} \mathrm{C}_{3}$ pyruvate, and $2 \mathrm{mM}$ AA solution) and with $(0.2 \mu \mathrm{g} / \mathrm{mL}$ of culture medium) or without $(0.0 \mu \mathrm{g} / \mathrm{mL}$ of culture medium) LPS, incubated.

${ }^{2}$ Values are moles of tracer $/ 100 \mathrm{~mol}$ of tracee. 
neous injections of TNF- $\alpha$ reduced the gluconeogenic capacity of liver by lowering the expression of $P C K 1$ and $G 6 P C$ but not that of $P C$ (Bradford et al., 2009). Furthermore, intramammary challenge with LPS resulted in the downregulation of key genes associated with hepatic gluconeogenesis (i.e., PCK1 and G6PC) in liver from lactating dairy cows (Jiang et al., 2008). Coupled with results from our study, the effect of in-
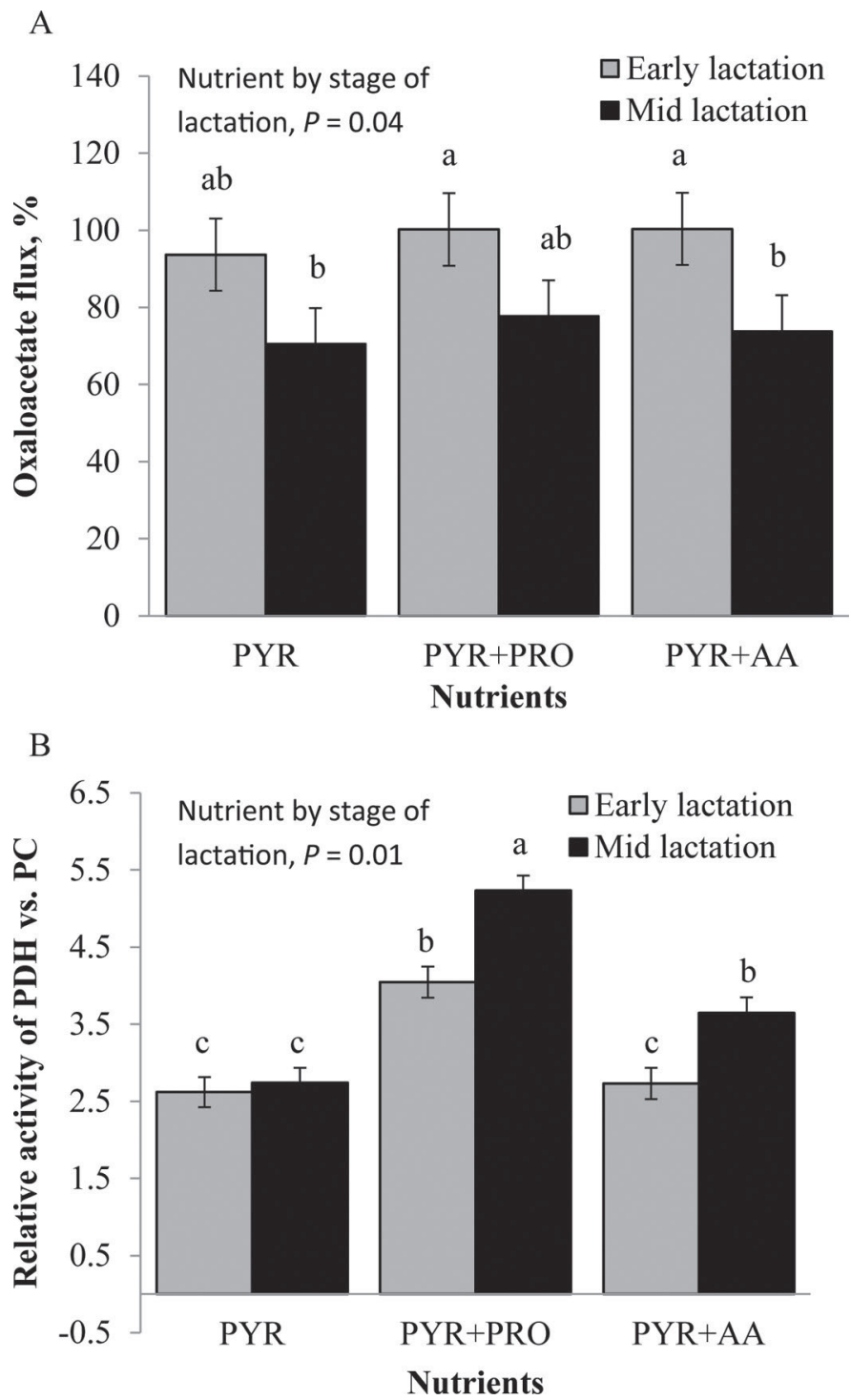

Figure 2. Contribution of pyruvate to oxaloacetate flux (A) and comparative activity of pyruvate dehydrogenase (PDH) versus pyruvate carboxylase (PC; B) from liver explants from Holstein cows in early $(\mathrm{n}=6)$ or mid lactation $(\mathrm{n}=6)$ incubated with either pyruvate (PYR; $1 \mathrm{~m} M$ unlabeled pyruvate and $1 \mathrm{~m} M{ }^{13} \mathrm{C}_{3}$ pyruvate), pyruvate + propionate $\left(\mathrm{PYR}+\mathrm{PRO} ; 1 \mathrm{~m} M\right.$ unlabeled pyruvate, $1 \mathrm{~m} M^{13} \mathrm{C}_{3}$ pyruvate, and $2 \mathrm{~m} M$ sodium propionate), or pyruvate + AA (PYR+AA; $1 \mathrm{~m} M$ unlabeled pyruvate, $1 \mathrm{mM}^{13} \mathrm{C}_{3}$ pyruvate, and $2 \mathrm{mM}$ AA solution) in vitro. Means with different letters $(\mathrm{a}-\mathrm{c})$ differ $(P \leq 0.05)$. Error bars represent treatment SEM.

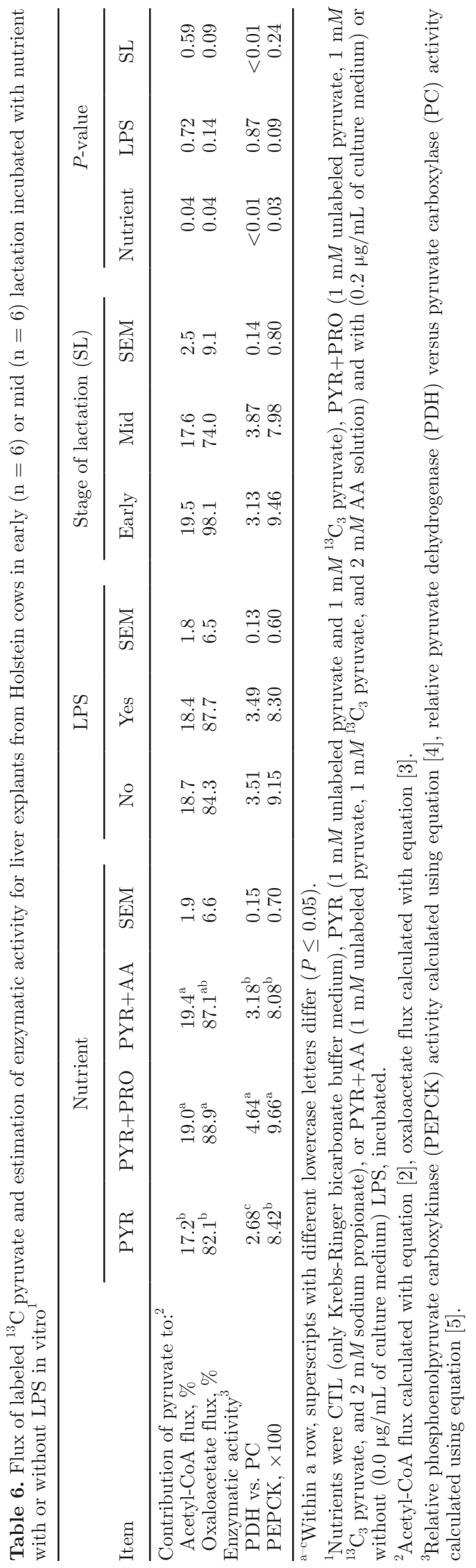

Journal of Dairy Science Vol. 98 No. 10, 2015 
flammation on the hepatic metabolic response warrants further investigation.

\section{Propionate and AA Increased Flux to Krebs Cycle Intermediates}

Supplementation of liver explants with gluconeogenic precursors such as propionate or AA (primarily the glucogenic AA, arginine and asparagine) were expected to contribute to the pool of nonlabeled oxaloacetate and other Krebs cycle intermediates, hence diluting the ${ }^{13} \mathrm{C}$ carbon contributed by $\left[{ }^{13} \mathrm{C} 3\right]$ pyruvate to Krebs cycle intermediates (Aiello et al., 1984; Wykes et al., 1998). Indeed, the incubation of liver slices with PYR compared with incubation with $\mathrm{PYR}+\mathrm{PRO}$ or $\mathrm{PYR}+\mathrm{AA}$ had greater enrichment of all alanine, aspartate, and glutamate isotopomers, indicating greater enrichment of pyruvate, oxaloacetate, and $\alpha$-ketoglutarate, respectively. Coupled with the reduced flux of ${ }^{13} \mathrm{C}$ carbon to generate acetyl-CoA or oxaloacetate, our results indicate that fewer carbons of pyruvate were incorporated for generation of Krebs cycle intermediates compared with liver supplemented with either propionate or AA.

Potential factors that contribute to a reduced replenishment of Krebs cycle intermediates in liver slices incubated with PYR may be due to reduced activity of PDH (i.e., a lower flux to acetyl-CoA) and PC (i.e.. a lower flux to oxaloacetate), leading to an accumulation of $\left[{ }^{13} \mathrm{C}\right]$ pyruvate, as verified by the increased concentrations of [M3]alanine with PYR. On the other hand, although flux to oxaloacetate was also similar between PYR and PYR+AA, incubation with either PYR + PRO or PYR+AA enhanced the flux of $\left[{ }^{13} \mathrm{C}\right]$ pyruvate to acetyl-CoA as well as to oxaloacetate (i.e., $\mathrm{PYR}+\mathrm{PRO}$ only) potentially by increasing the activity of both PDH and PC. Indeed, the greatest increase in activity of PDH versus $\mathrm{PC}$ was observed in PYR+PRO followed by PYR+AA. This provides further support that both propionate and AA were used as anaplerotic substrates to replenish Krebs cycle intermediates and to provide intermediary products for other anabolic process such as gluconeogenesis, whereas limited supplementation of nutrients (i.e., PYR) may impair liver function.

\section{Gluconeogenesis Was Increased with Propionate Supplementation}

Regardless of stage of lactation and LPS challenge, the greater $\mathrm{PDH}$ versus $\mathrm{PC}$ activity in liver explants incubated with $\mathrm{PYR}+\mathrm{PRO}$ compared with $\mathrm{PYR}+\mathrm{AA}$ indicates that propionate provides carbons used for the generation of oxaloacetate available for gluconeogenesis through PEPCK, thereby reducing the demand for the generation of oxaloacetate via PC (Aschenbach et al., 2010). Therefore, the available pyruvate can be used for synthesis of acetyl-CoA (Owen et al., 2002). This result is further supported by the downregulation of $P C$ in liver explants incubated with propionate compared with AA. Others have also reported that expression of $P C$ is reduced as a result of reduced DMI decreasing the production of propionate by rumen microbia (Greenfield et al., 2000; Graber et al., 2010). Furthermore, activity of PEPCK, a major enzyme involved in gluconeogenesis, was greatest for PYR $+\mathrm{PRO}$ compared with PYR and PYR $+\mathrm{AA}$, providing additional evidence that propionate supplementation is the preferred substrate for gluconeogenesis in the liver for cattle. The expression of PEPCK-cytosolic (PCK1) was not altered by nutrient supplementation. Moreover, the calculation of PEPCK activity cannot differentiate between mitochondrial and cytosolic activity, therefore limiting our interpretation on the contrasting results between genomic and fluxomic data for PEPCK activity.

\section{Stage of Lactation Altered Hepatic Metabolism}

Regardless of nutrient supplement or LPS challenge, liver explants from cows in early lactation had lower [M3]alanine, [M1] and [M2] glutamate, and [M2] acetyl CoA isotopomers compared with cows in mid lactation. Lower [M3]alanine enrichment indicates a dilution of ${ }^{13} \mathrm{C}$ pyruvate by other sources of nonlabeled pyruvate such as lactate, which is a major contributor for hepatic gluconeogenesis in cows in early compared with cows in mid lactation (Doepel et al., 2009). Moreover, lower [M1] and [M2] glutamate enrichment reflects lower contribution of labeled $\alpha$-ketoglutarate from [M2] acetyl-CoA and [M2] and [M3]oxaloacetate compared with mid-lactation cows (Pascual et al., 1998; Wykes et al., 1998). Early lactation may have had an increased removal of intermediates via cataplerotic reactions based on the tendency for a greater flux of pyruvate to oxaloacetate and the lower PDH versus PC activity, supported by an upregulation of $P C$, indicating an increase in gluconeogenesis compared with cows in mid lactation. Furthermore, the expression of $P C$ that reflected a direct increase on enzymatic activity of $\mathrm{PC}\left(\mathrm{r}^{2}\right.$ $=0.89$ ) increased for cows at 1 to 28 DIM and declined to precalving levels by 56 DIM, indicating a decrease in the demand for gluconeogenic precursors as lactation progresses (Greenfield et al., 2000; Weber et al., 2013). Coupled with higher circulating NEFA and BHBA, our results confirm that cows in early lactation were experiencing negative energy balance when compared with cows in mid lactation. 


\section{CONCLUSIONS}

Liver explants challenged with LPS resulted in an inflammatory condition via the upregulation of TNFA, $H P$, and $S A A$, and increased concentrations of TNF- $\alpha$ in media. Inflammatory LPS challenge in vitro resulted in changes in hepatic metabolism via a reduced enrichment of [M1] and [M2]alanine and a tendency for reduced enzymatic activity of PEPCK. Nutrient supply did not affect the hepatic metabolic response during LPS challenge in vitro. Regardless of stage of lactation and LPS challenge, addition of propionate or AA replenished Krebs cycle intermediates compared with pyruvate alone, and propionate was the preferred substrate for gluconeogenesis rather than AA. The lower $\mathrm{PDH}$ versus $\mathrm{PC}$ activity for cows in early lactation reflects greater contribution of pyruvate to the flux of oxaloacetate when compared with cows in mid lactation. Our results suggest that hepatic gluconeogenesis was impaired during inflammation and this response is independent of stage of lactation and nutrient supplementation in vitro. Further research examining how various nutrients support liver function to enhance hepatic immunometabolic response during inflammation and thereby improve animal health and economic outcome for the farmer is warranted.

\section{ACKNOWLEDGMENTS}

This study was funded via the Maryland Agricultural Experiment Station of the College of Agriculture and Natural Resources at the University of Maryland, College Park. The authors acknowledge the staff of the University of Maryland Dairy Research Unit (Clarksville) for their assistance with animal care and data collection.

\section{REFERENCES}

Aiello, R. J., T. M. Kenna, and J. H. Herbein. 1984. Hepatic gluconeogenesis and ketogenic interrelationships in the lactating cow. J. Dairy Sci. 67:1707-1715.

Aschenbach, J. R., N. B. Kristensen, S. S. Donkin, H. M. Hammon, and G. B. Penner. 2010. Gluconeogenesis in dairy cows: The secret of making sweet milk from sour dough. IUBMB Life 62:869-877.

Bequette, B. J., N. E. Sunny, S. W. El-Kadi, and S. L. Owens. 2006. Application of stable isotopes and mass isotopomer distribution analysis to the study of intermediary metabolism of nutrients. J. Anim. Sci. 84:E50-E59.

Bionaz, M., E. Trevisi, L. Calamari, F. Librandi, A. Ferrari, and G. Bertoni. 2007. Plasma paraoxonase, health, inflammatory conditions and liver function in transition dairy cows. J. Dairy Sci. 90:1740-1750.

Bradford, B. J., L. K. Mamedova, J. E. Minton, J. S. Drouillard, and B. J. Johnson. 2009. Daily injection of tumor necrosis factor- $\alpha$ increases hepatic triglycerides and alters transcript abundance of metabolic genes in lactating dairy cattle. J. Nutr. 139:1451-1456.

Brauman, J. 1966. Least squares analysis and simplification of multiisotope mass spectra. Anal. Chem. 38:607-610.
Carlson, D. B., N. Litherland, H. Dann, J. Woodworth, and J. Drackley. 2006. Metabolic effects of abomasal L-carnitine infusion and feed restriction in lactating Holstein cows. J. Dairy Sci. 89:48194834.

Ceciliani, F., J. J. Ceron, P. D. Eckersall, and H. Sauerwein. 2012. Acute phase protein in ruminants. J. Proteomics 75:4207-4231.

Chapinal, N., M. Carson, T. Duffield, M. Capel, S. Godden, M. Overton, J. Santos, and S. LeBlanc. 2011. The association of serum metabolites with clinical disease during the transition period. J. Dairy Sci. 94:4897-4903.

Doepel, L., G. E. Lobley, J. F. Bernier, P. Dubreuil, and H. Lapierre. 2009. Differences in splanchnic metabolism between late gestation and early lactation dairy cows. J. Dairy Sci. 92:3233-3243.

Drackley, J. K., D. Beitz, and J. Young. 1991. Regulation of in vitro palmitate oxidation in liver from dairy cows during early lactation. J. Dairy Sci. 74:1884-1892.

Drackley, J. K., H. M. Dann, G. N. Douglas, N. A. J. Guretzky, N. B. Litherland, J. P. Underwood, and J. J. Loor. 2005. Physiological and pathological adaptations in dairy cows that may increase suseptibility to periparturient diseases and disorders. Ital. J. Anim. Sci. 4:323-344.

Eckersall, P. D., F. Young, C. McComb, C. Hogarth, S. Safi, A. Weber, T. McDonald, A. Nolan, and J. Fitzpatrick. 2001. Acute phase proteins in serum and milk from dairy cows with clinical mastitis. Vet. Rec. 148:35-41.

El-Kadi, S. W., R. L. Baldwin, K. R. McLeod, N. E. Sunny, and B. J. Bequette. 2009. Glutamate is the major anaplerotic substrate in the tricarboxylic acid cycle of isolated rumen epithelial and duodenal mucosal cells from beef cattle. J. Nutr. 139:869-875.

Graber, M., S. Kohler, T. Kaufmann, M. G. Doherr, R. M. Bruckmaier, and H. A. van Dorland. 2010. A field study on characteristics and diversity of gene expression in the liver of dairy cows during the transition period. J. Dairy Sci. 93:5200-5215.

Greenfield, R. B., M. Cecava, and S. Donkin. 2000. Changes in mRNA expression for gluconeogenic enzymes in liver of dairy cattle during the transition to lactation. J. Dairy Sci. 83:1228-1236.

Griffin, J. L., and C. Des Rosiers. 2009. Applications of metabolomics and proteomics to the mdx mouse model of Duchenne muscular dystrophy: Lessons from downstream of the transcriptome. Genome Med. 1:32.

Grummer, R. R. 1995. Impact of changes in organic nutrient metabolism on feeding the transition dairy cow. J. Anim. Sci. 73:28202833.

Hammon, D., I. Evjen, T. Dhiman, J. Goff, and J. Walters. 2006. Neutrophil function and energy status in Holstein cows with uterine health disorders. Vet. Immunol. Immunopathol. 113:21-29.

Huzzey, J., T. Duffield, S. LeBlanc, D. Veira, D. Weary, and M. Von Keyserlingk. 2009. Short communication: Haptoglobin as an early indicator of metritis. J. Dairy Sci. 92:621-625.

Ingvartsen, K. L. 2006. Feeding- and management-related disease in the transition cow: Physiological adaptation around calving and strategies to reduce feeding-related diseases. Anim. Feed Sci. Technol. 126:175-213.

Ingvartsen, K. L., and K. Moyes. 2013. Nutrition, immune function and health of dairy cattle. Animal 7:112-122.

Janovick-Guretzky, N. A., H. M. Dann, D. B. Carlson, M. R. Murphy, J. J. Loor, and J. K. Drackley. 2007. Housekeeping gene expression in Bovine liver is affected by physiological state, feed intake, and dietary treatment. J. Dairy Sci. 90:2246-2252.

Jiang, L., P. Sørensen, C. Røntved, L. Vels, and K. L. Ingvartsen. 2008. Gene expression profiling of liver from dairy cows treated intramammary with lipopolysaccharide. BMC Genomics 9:443.

Jørgensen, H. B., B. Buitenhuis, C. M. Røntved, L. Jiang, K. L. Ingvartsen, and P. Sørensen. 2012. Transcriptional profiling of the bovine hepatic response to experimentally induced E. coli mastitis. Physiol. Genomics 44:595-606.

Kadegowda, A. K. G., M. Bionaz, B. Thering, L. S. Piperova, R. A. Erdman, and J. J. Loor. 2009. Identification of internal control genes for quantitative polymerase chain reaction in mammary tissue of lactating cows receiving lipid supplements. J. Dairy Sci. 92:2007-2019. 
Livak, K. J., and T. D. Schmittgen. 2001. Analysis of relative gene expression data using real-time quantitative PCR and the $2(-$ delta delta $\mathrm{C}(\mathrm{T})$ ) method. Methods 25:402-408.

Loor, J. J., H. M. Dann, R. E. Everts, R. Oliveira, C. A. Green, N. A. Guretzky, S. L. Rodriguez-Zas, H. A. Lewin, and J. K. Drackley. 2005. Temporal gene expression profiling of liver from periparturient dairy cows reveals complex adaptive mechanisms in hepatic function. Physiol. Genomics 23:217-226.

Mallard, B. A., J. Dekkers, M. Ireland, K. Leslie, S. Sharif, C. Lacey Vankampen, L. Wagter, and B. Wilkie. 1998. Alteration in immune responsiveness during the peripartum period and its ramification on dairy cow and calf health. J. Dairy Sci. 81:585-595.

McCarthy, S. D., S. M. Waters, D. A. Kenny, M. G. Diskin, R. Fitzpatrick, J. Patton, D. C. Wathes, and D. G. Morris. 2010. Negative energy balance and hepatic gene expression patterns in highyielding dairy cows during the early postpartum period: A global approach. Physiol. Genomics 42A:188-199.

Moyes, K. M., J. K. Drackley, J. L. Salak-Johnson, D. E. Morin, J. C. Hope, and J. J. Loor. 2009a. Dietary-induced negative energy balance has minimal effects on innate immunity during a Streptococcus uberis mastitis challenge in dairy cows during mid lactation. J. Dairy Sci. 92:4301-4316.

Moyes, K. M., T. Larsen, N. Friggens, J. Drackley, and K. L. Ingvartsen. 2009b. Identification of potential markers in blood for the development of subclinical and clinical mastitis in dairy cattle at parturition and during early lactation. J. Dairy Sci. 92:5419-5428.

Moyes, K. M., T. Larsen, P. Sørensen, and K. L. Ingvartsen. 2014 Changes in various metabolic parameters in blood and milk during experimental Escherichia coli mastitis for primiparous Holstein dairy cows during early lactation. J. Anim. Sci. Biotechnol. 5:47.

NRC. 2001. Nutrient Requirements of Dairy Cattle. 7th rev. ed. Natl. Acad. Sci., Washington, DC.

Ospina, P. A., D. Nydam, T. Stokol, and T. Overton. 2010. Evaluation of nonesterified fatty acids and $\beta$-hydroxybutyrate in transition dairy cattle in the northeastern United States: Critical thresholds for prediction of clinical diseases. J. Dairy Sci. 93:546-554.

Owen, O. E., S. C. Kalhan, and R. W. Hanson. 2002. The key role of anaplerosis and cataplerosis for citric acid cycle function. J. Biol. Chem. 277:30409-30412.
Pascual, M., F. Jahoor, and P. J. Reeds. 1998. In vivo glucose contribution to glutamate synthesis is maintained while its contribution to acetyl CoA is lowered in adult mice fed a diet with a high fat: carbohydrate ratio. J. Nutr. 128:733-739.

Qu, Y., A. N. Fadden, M. G. Traber, and G. Bobe. 2014. Potential risk indicators of retained placenta and other diseases in multiparous cows. J. Dairy Sci. 97:4151-4165.

Saremi, B., H. Saurwein, S. Dänicke, and M. Mielenz. 2012. Technical note: Identification of reference genes for gene expression studies in different bovine tissues focusing on different fat depots. J. Dairy Sci. 95:3131-3138.

Sordillo, L. M., G. Contreras, and S. L. Aitken. 2009. Metabolic factors affecting the inflammatory response of periparturient dairy cows. Anim. Health Res. Rev. 10:53-63.

Vandesompele, J., P. K. De, F. Pattyn, B. Poppe, R. N. Van, P. A. De, and F. Speleman. 2002. Accurate normalization of real-time quantitative RT-PCR data by geometric averaging of multiple internal control genes. Genome Biol. 3:RESEARCH0034.

Vels, L., C. M. Rontved, M. Bjerring, and K. L. Ingvartsen. 2009. Cytokine and acute phase protein gene expression in repeated liver biopsies of dairy cows with a lipopolysaccharide-induced mastitis. J. Dairy Sci. 92:922-934.

Waldron, M. R., A. Kulick, A. Bell, and T. Overton. 2006. Acute experimental mastitis is not causal toward the development of energy-related metabolic disorders in early postpartum dairy cows. J. Dairy Sci. 89:596-610.

Waldron, M. R., T. Nishida, B. Nonnecke, and T. Overton. 2003 Effect of lipopolysaccharide on indices of peripheral and hepatic metabolism in lactating cows. J. Dairy Sci. 86:3447-3459.

Weber, C., C. Hametner, A. Tuchscherer, B. Losand, E. Kanitz, W. Otten, H. Sauerwein, R. M. Bruckmaier, F. Becker, W. Kanitz, and H. M. Hammon. 2013. Hepatic gene expression involved in glucose and lipid metabolism in transition cows: Effects of fat mobilization during early lactation in relation to milk performance and metabolic changes. J. Dairy Sci. 96:5670-5681.

Wykes, L. J., F. Jahoor, and P. J. Reeds. 1998. Gluconeogenesis measured with [U-13C] glucose and mass isotopomer analysis of apoB100 amino acids in pigs. Am. J. Physiol. 274:E365-E376. 